\title{
Prospecting history leading to the discovery of Botswana's diamond mines: from artefacts to Lesedi La Rona
}

\author{
Michiel C J de Wit
}

M de Wit

dewit@icon.co.za

Tsodilo Resources Ltd. P O Box 3726 Gaborone Botswana

University of Pretoria Department of Geology University Road Pretoria 0002 South Africa

\begin{abstract}
Bechuanaland/Botswana has a long and colourful history in exploration and mining. Here these activities are subdivided into three phases: pre-historic, historic and modern. Quarrying stone in Botswana was ongoing 500,000 years ago during the Early Stone Age (ESA). Actual mining of stones probably only started during the Middle Stone Age (MSA) i.e. post 250,000 BP, and the first prehistoric hard rock mining of specularite and limonite, likely started during the Late Stone Age (LSA) 20,000 to 2,000 BP. In east Botswana iron and copper were mined from AD 800 onwards; the mining of gold started in the $13^{\text {th }}$ century. Historic mining started with the re-discovery of gold close to Francistown in 1865 and lasted until the 1950s. Rumours of diamonds in Bechuanaland had already surfaced in the 1880s, and it was Ngamiland,
\end{abstract}


in the northwest, that was first explored systematically for diamonds and gold between 1896 and 1899. A joint initiative between Anglo American and De Beers started serious prospecting parts of eastern Bechuanaland between 1932 and 1938; and in 1938 the first diamond finds in Bechuanaland were reported. Modern mining started with the signing of an agreement in 1959, allowing Consolidated African Selection Trust Ltd (CAST) into the Bamangwato Tribal Reserve. CAST found a few diamonds in the Motloutse River, but concluded that these were reworked and dropped the exploration rights. De Beers believed that these diamonds had come from west of the Motloutse headwaters, across the watershed in the Kalahari. This ultimately led to the discovery of the Orapa kimberlite field in 1967, a year after Botswana became independent. This discovery triggered a major exploration boom across Botswana adding important diamondbearing kimberlites such as at Letlhakane (1970), Jwaneng (1973), Gope (1981) and Lerala (1991).

\section{Key words:}

Prospecting

Botswana

History

Character count: $\quad$ 46,763 Characters (with spaces)

39,235 Characters (no spaces) 


\section{Introduction}

The history of exploration and mining in the area known as Botswana goes back a long way. To appreciate the development of diamond prospecting across this region, it is necessary to take cognisance of the long and innovative path that exploration and mining have followed since early humans. Botswana's mining past can be subdivided into three phases: pre-historic, historic and modern exploration and mining. Although diamonds only started to come into play in the latter two stages, it is interesting to speculate whether early man would have picked up any 'shiny' stones while walking over the large Orapa crater on the edge of the Makgadikgadi pans (Fig. 1).

\section{Pre-historic mining}

Early evidence of pre-historic 'mining' with local beneficiation has been described from archaeological 'factory' sites at outcropping rocks bearing conchoidal fractures such as silcrete and basalt along the edges of the Makgadikgadi pans (Ebert 1979), and along the banks of some rivers, such as the Boteti River (Fig. 1) (Cooke 1979). The pans are remnants of former inland lakes with palaeo-shorelines preserved at different elevations $(\sim 995 \mathrm{~m}, 945 \mathrm{~m}, 936 \mathrm{~m}, 920 \mathrm{~m}$ and $912 \mathrm{~m}$ ) and artefacts generally become younger at successive lower shorelines (Moore et al. 2012).

Early Stone Age (ESA 2.0-0.3Ma), Middle Stone Age (MSA 250-22Ka) and Late Stone Age (LSA 22 - 2Ka) sites occur on the various lake floors, including those close to the present 


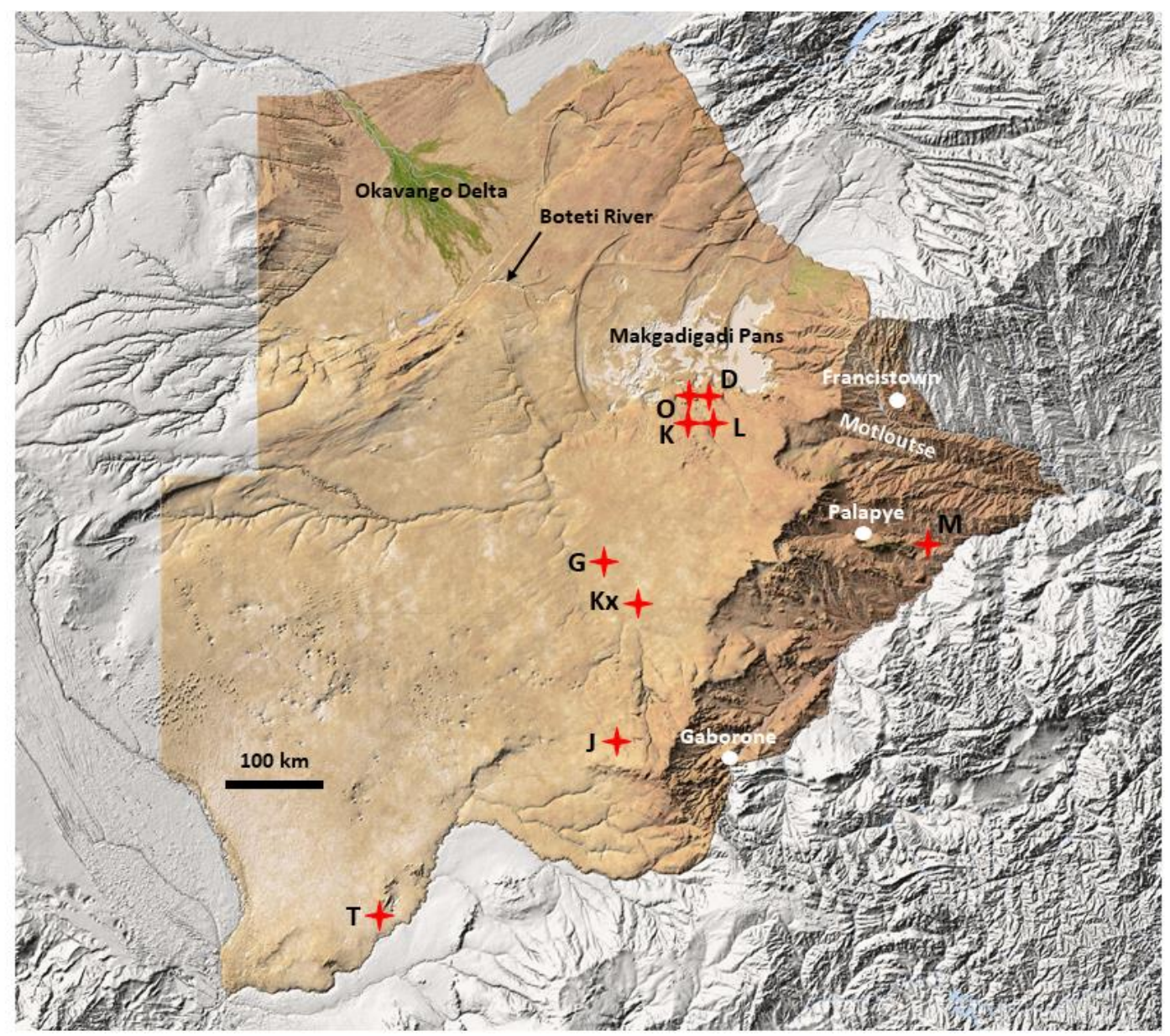

Fig. 1 Elevation map of Botswana, clearly showing the cut back of the Motloutse River into Du Toit's NE-SW orientated 'upwarp' (source: Shutterstock.com). D= Damtshaa Mine, G= Ghaghoo Mine, J= Jwaneng Mine, K=Karowe (AK06) Mine, Kx= KX36 prospect Mine, $\mathrm{L}=$ Letlhakane Mine, $\mathrm{M}=$ Martin's Drift (Lerala) kimberlites, $\mathrm{O}=$ Orapa (AK01) Mine, $\mathrm{T}=$ Tsabong M1 kimberlite 
Orapa kimberlite field. During the stripping for the open pits of two of the kimberlites of the Damtshaa diamond mine (Fig. 1), small silcrete artefacts from the earliest ESA (Oldowan culture; $1.5-2 \mathrm{Ma}$ ) were found at the base of the Kalahari sand just above the calcretised kimberlites 2125B/K9 (Walker 2001) and 2125B/K12 (Jim Gibson pers. comm. 2017). These tools were likely produced by Homo habilis, who flaked off pebbles to create a sharp chopping edge.

During the subsequent Acheulian (0.5-1.5 Ma), Homo erectus appeared to have repeatedly returned to areas with an abundance of such stones, to 'quarry' and make large bifacial tools (Tlou and Campbell 1997). This is seen for instance at Chanoga along the Boteti River (Fig. 1), where hard silcrete is readily available, and where a large concentration of hand axes was found (Cooke 1979).

During the MSA and LSA periods, fragments would be broken from an outcrop, or rocks were dug out during rudimentary "mining”. This has been described also in the Bobonong area, where fragments of chert, agate and silcrete were taken directly from outcrops for tool making (van Waarden 1989). It has been suggested that MSA tools at Tsodilo Hills (Fig. 1) have come from a variety of silcrete sources, some as far away as Lake Ngami and the Boteti River, up to $300 \mathrm{~km}$ away (Nash et al. 2016).

From the $9^{\text {th }}$ to the $14^{\text {th }}$ century, specularite and hematite were mined from hard rock at Tsodilo Hills and used as pigment for cosmetic and decorative purposes (Campbell et al. 2010). Another specularite mine (AD1000-1300) is located at Matsiloje near Francistown (van Waarden pers. comm. 2016), and two specularite deposits, west of Gaborone were mined from the $14^{\text {th }}$ to $18^{\text {th }}$ century (Campbell and Main 2003). 
LSA rock paintings by KhoeSan at the Thune Dam in eastern Botswana, have recently been carbon dated c. 2000 to $5000 \mathrm{BP}$ (Bonneau et al. 2017). The samples occur in association with red and yellow pigments, for which ochreous hematite and limonite were used. Other rock paintings using similar pigments occur at Tsodilo Hills and at Manyana. Red ochre was also widely used as a cosmetic by San and other groups in the northwest. From the $7^{\text {th }}$ to the $10^{\text {th }}$ Century red ochre and black graphite was used by the first farming communities in northern Botswana, and later by the Kalanga people for decoration of pottery (Tlou and Campbell 1997).

Farmers who arrived in Botswana as part of the Bantu migration from the north in the $8^{\text {th }}$ century, came with knowledge of mining, smelting and smithing of copper and iron, and soon found local ores to use. Copper deposits in northeast Botswana in the Matsitama Greenstone Belt and associated Bushman Shear Zone, the Selkirk Formation and the Limpopo Mobile Belt, were all mined in prehistoric times, of which the largest were the Dukwe, Thakadu and Selkirk mines (Huffman et al. 1995; van Waarden 2014). These mines operated between AD1400 and 1700, supplying regional demand within the Kalanga State.

The main sources of iron were from mines on the east side of the Tswapong Hills, near Palapye (Fig. 1). Many smelter sites occur along the base of these hills where ironstone was collected from the slopes. Some iron smelters here date back to c. AD 800-1000 (KiyagaMulindwa 1992).

There are about 200 known ancient gold workings in the Tati and Vuma Greenstone belts (Summers 1969; Key 1976). Because most of those mines were subsequently reworked by Europeans between 1868 and 1930, much of the pre-historic evidence has been lost. However, crucibles with tiny gold specks found at the Mupanipani Ruin, south of Francistown, were dated at c. AD 1275-1285 (van Waarden 2011). Similar crucibles from a Leopard's Kopje site are 
likely from the $11^{\text {th }}-13^{\text {th }}$ century. A fragment of a gold bangle found at the Domboshaba ruins north of Francistown, which was occupied from c. AD 1300-1600 during the early Zimbabwe period and the Khami phase. Mining probably continued here until the Matebele invasion c. 1830 (van Waarden 2012).

\section{Historic mining}

Henry Hartley re-discovered gold near the lower Tati River in 1865 during a hunting trip to Matabeleland, most of which later formed part of Rhodesia, now Zimbabwe (Tabler 1966). The presence of gold was confirmed by geologist Karl Mauch, who announced the discovery in 1867 (Davenport 2015). This marks the start of the historic mining phase in Bechuanaland. They found the area virtually abandoned by the Kalanga, who had fled their ancestral land after being raided by the Matabele around 1839. The gold rush started at the Tati settlement (now called "Old Tati”) in 1868, and thereafter spread across the whole of the Tati Greenstone Belt.

A time of uncertainty, followed when Mzilikazi of the Matabele died in 1868 and was succeeded by King Lobengula, and also because there was a succession dispute among the Bangwato. Some European prospectors took advantage of this uncertainty and obtained the Tati Mining Concession from Lobengula, in the name of the London and Limpopo Mining Co.

This concession was almost abandoned in 1872 when most prospectors rushed to the diamond fields around Kimberley, and in 1880 the Tati concession (Fig. 2) was taken over by the 


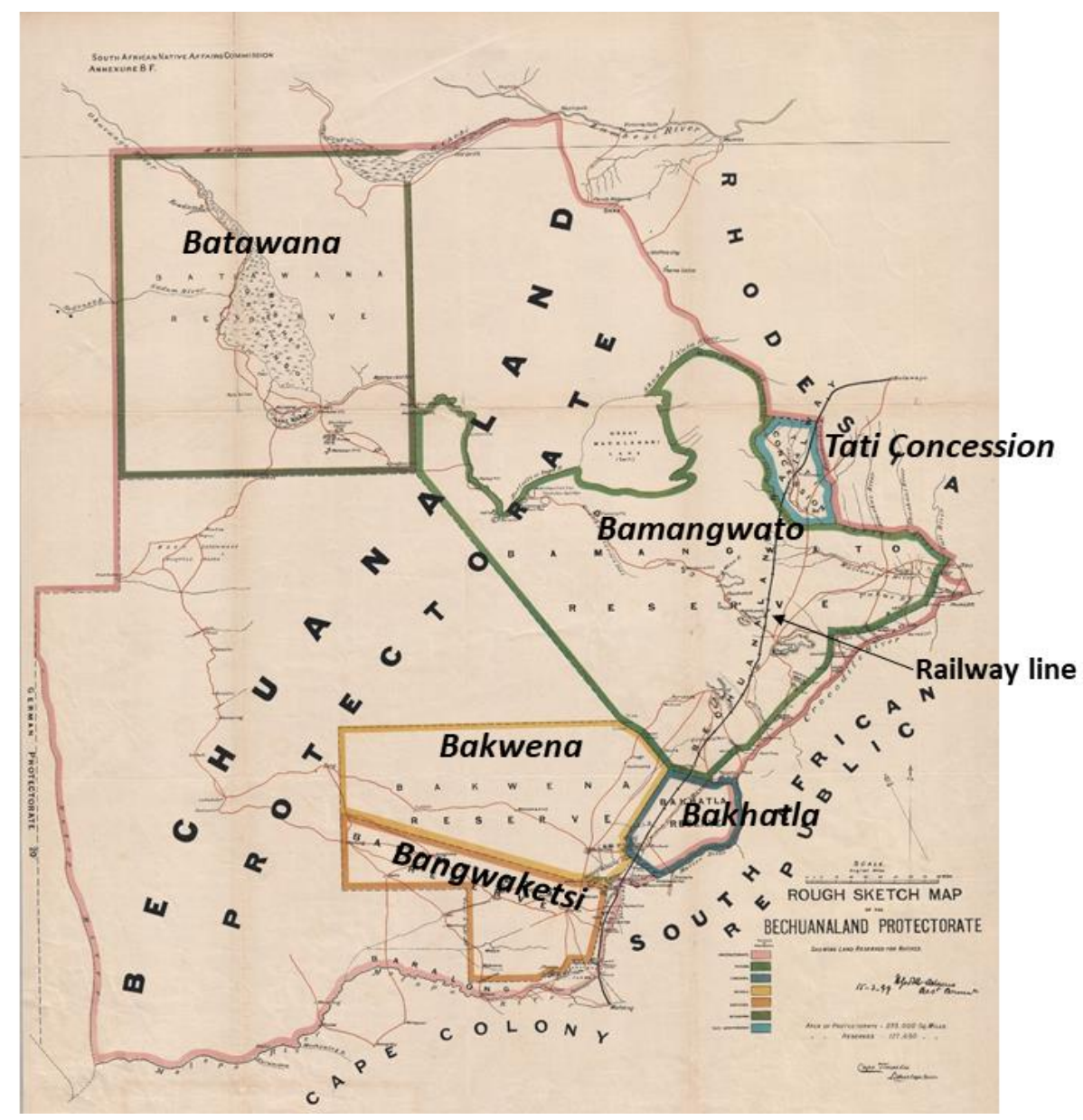

Fig. 2 Map showing tribal reserves in the Bechuanaland Protectorate in 1899 (source: UCT Map Library Collections, Cape Town; permission to use) 
Northern Light Gold and Exploration Co., which later became the Tati Company. Mining resumed here between 1881 and 1898 with the focus on the Monarch Mine and Todd's Creek. Francistown was established subsequently when the railway was completed there in 1897.

The Bushman Copper Mine near Dukwe (now Mowana Mine) was granted to the Bamangwato after they helped the British South Africa Company (BSAC) to defeat the Matabele in 1893, and from 1901 to 1918 it was operated by the BSAC under licence from the Bangwato. Later the Bangwato also started Bamangwato Concessions Ltd (BCL) to mine the copper at Selebi-Phikwe.

During the colonisation of Africa, the British Government declared southern and northern Bechuanaland their Protectorate in 1885 and 1890, respectively. However, there was great concern that Bechuanaland would be annexed to the Cape Colony and become part of Rhodes' empire. For the BSAC, Bechuanaland became important not only because of the gold discoveries in the Tati area and the potential of finding other mineral deposits, but also because by 1897 the railway in eastern Bechuanaland, linking Kimberley and the Rhodesias, was completed (Fig. 2). Because of these developments, the Chiefs from Bamangwato (Khama III), Bakwena (Sebele I) and Bangwaketse (Bathoen I) travelled to England in 1895 to plead to remain under the Queens Protectorate and not to be overtaken by the BSAC (Fig. 3). Despite objections from Rhodes, the British Government agreed that Bechuanaland would remain a British Protectorate, which it did until its independence in 1966.

In 1887 Khama III signed an agreement with the Northern Gold Fields Exploration Syndicate giving them the right to prospect for precious stones and minerals in his territory (Crowder 1985). This concession was taken over by the BSAC in 1893 but the terms were 


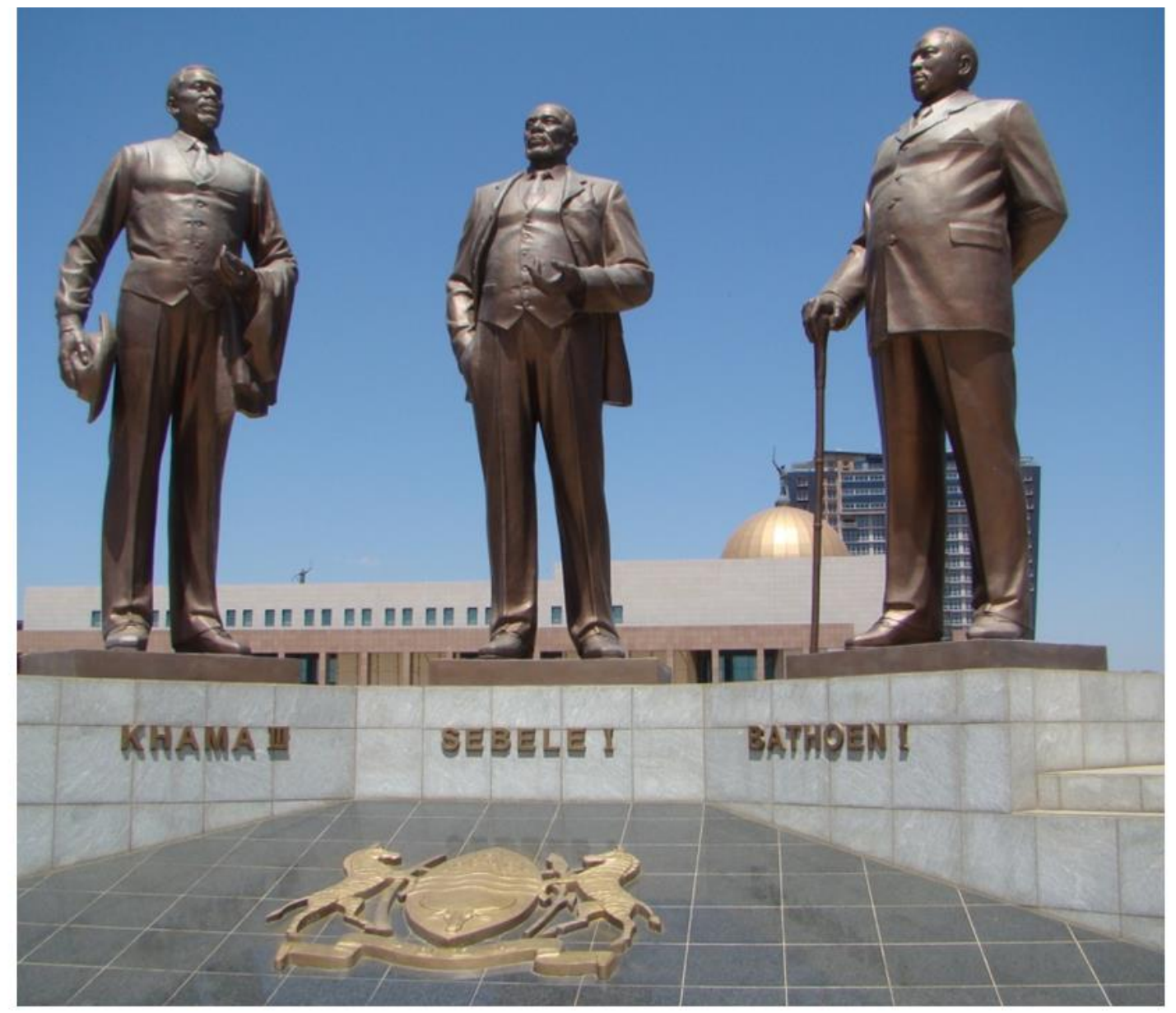

Fig. 3 The Three Dikgosi Monument in Gaborone; Khama III, Sebele I and Bathoen I. They travelled to Great Britain in 1895 to ask for protection from the BSAC 
challenged particularly by Khama's successor, Tshekedi Khama. It was only in March 1932 that Tshekedi signed a much revised agreement on behalf of the Bamangwato tribe (Crowder 1985).

In 1887 and 1888 two further concessions were granted to prospect for precious stones and other minerals in the Bangwaketse reserve (Fig. 2). Both these concessions were acquired by Balkis Ltd who had offered them to De Beers (du Toit 1934a). Interestingly Dr Beetz, a consultant to De Beers, reported in 1928 that gravels had been tested in the same area, but that no diamonds had been found (du Toit 1934a).

The first substantial organized program to search for diamonds and gold was initiated by the British West Charterland Ltd (BWC) between 1896 and 1899. BWC sent an expedition to Ngamiland in northwest Botswana (Fig. 4), which was initially led by Sir Frederick Lugard, a close friend of Cecil John Rhodes (Passarge 1904). The technical person of this expedition was Siegfried Passarge, a medical doctor by training, turned geographer and author of 'Die Kalahari' (1904). This book describes in detail the geography, eco-social systems of the region, and for example, the use of termites to map subsurface geology. However, he was prevented from reporting any mineralogical results. Despite these restrictions, the book has some very detailed geological maps of the area (Fig. 5), and Du Toit (1932) noted that the area was mapped and examined 'in minute detail', but that the results were disappointing viz exploration goals (du Toit 1931). 


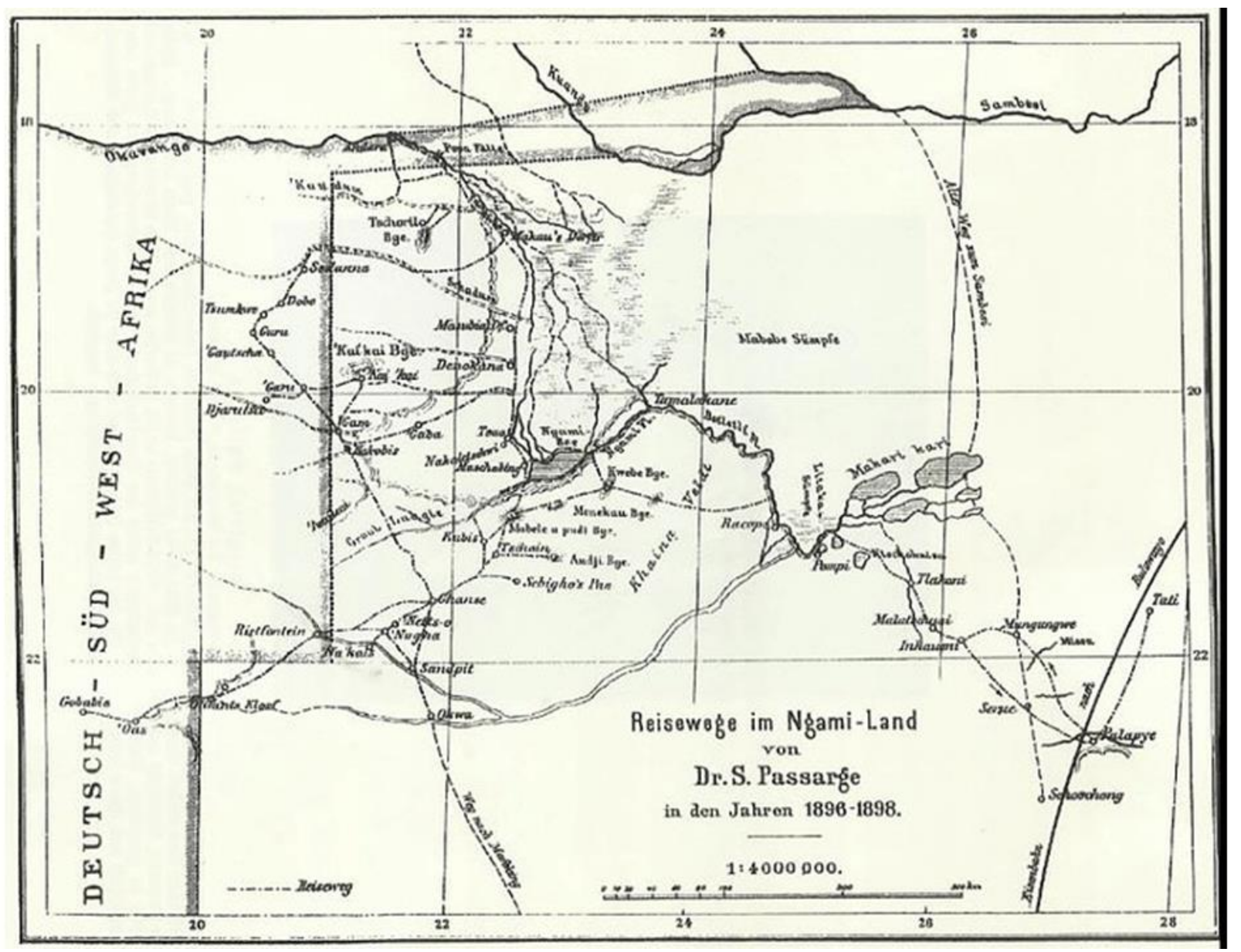

Fig. 4 Map showing the various routes that Passarge travelled while exploring Ngamiland (Passarge 1905) 


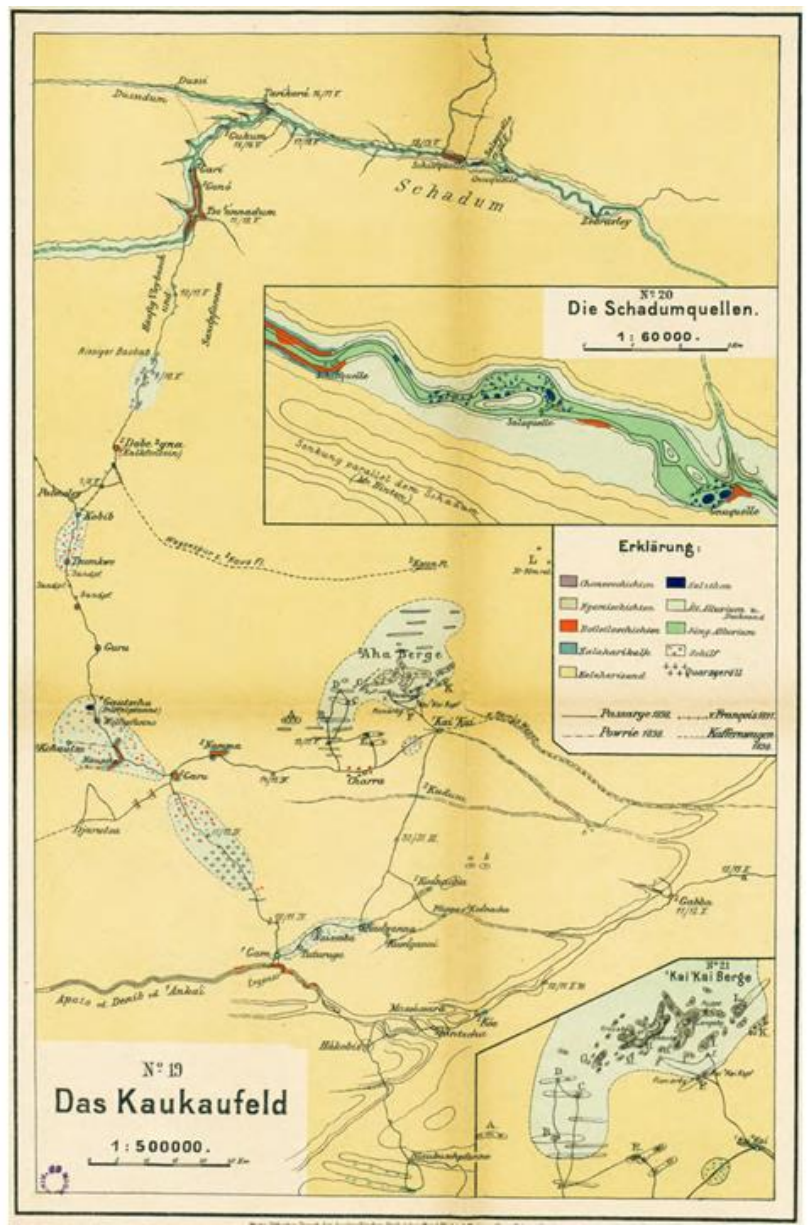

Fig. 5 Geological Map of the 'Das Kaukaufeld', straddling the Namibia/Botswana border, showing the Xaudum Valley in the north as drawn by Siegfried Passarge (1904). Between 1979 and 2011 some 44 kimberlites were discovered in or close to this valley, none of which were reported by Passarge 


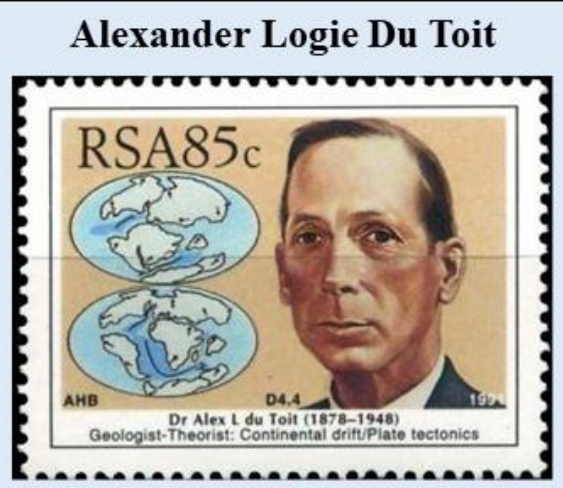

$1878-1948$

- 1903 - 1920: Geological Commission of the Cape of Good Hope

- 1920 - 1927: Union Irrigation Department as water geologist and spent 1925 in northern Botswana

- 1927-1941: Chief Consulting Geologist to De Beers Consolidated Mines (Pty) Ltd

- 1932 - 1938: Prospected parts of Botswana (Victoria Prospecting Company Ltd)

- 1937: His well known publication 'Our wandering continents' expanded and improved on Wegener's continental drift ideas

- 1947 External Examiner to G Lamont's PhD

Fig. 6 Summary profile of Dr Alex Du Toit, renowned South African geologist, involved in Botswana as a public servant and later linked to industry (AAC/De Beers) 


\section{A L du Toit}

Alex du Toit (Fig. 6) was the first of three people who contributed significantly to the diamond exploration success in Botswana. While working for the Union Irrigation Department in South Africa he was sent to northern Botswana in 1925 to check whether the Okavango/Chobe Rivers could be diverted into the Makgadikgadi basin, thereby flooding it. It had been suggested by Schwarz (1920) that evaporation of the flooded basin would enhance rainfall over the entire Kalahari region. During this work Du Toit gained a deep insight into the geomorphology of the Kalahari basin (du Toit 1927) and published an important paper on crustal warping (du Toit 1933), which later became the key to the discovery of the Orapa kimberlites.

When the oldest son of Khama III, Sekgoma, died in 1925 his son, Seretse Khama, was only 4 years old and too young to ascend the throne. Thus Sekgoma's half-brother, Tshekedi, became the regent of the Bamangwato (Fig. 7). As mentioned above, he eventually signed an agreement with the BSAC in 1932, in which the Resident Commissioner Lt Col. C.F. Rey played a major facilitating role (du Toit 1932). Some of the meetings between Du Toit and Rey are detailed in Rey's biography (Rey 1988).

Du Toit (1931) believed strongly that kimberlites were present in Bechuanaland and he proposed to Anglo American Corporation (AAC) to focus on eastern Bechuanaland mainly because it is well-exposed but also since other areas, like Ngamiland, had already been explored. Du Toit suggested that gravels along the major rivers needed to be mapped for testing; this was approved for a period of 18 months in 1932. The project was executed under the Victoria Prospecting Company Ltd and field work was managed by Dr TD Guernsey who reported directly to Dr 'Joe' Bancroft (AAC). Du Toit represented De Beers, and De Beers contributed $20 \%$ to a sum of $£ 4,500$. 


\section{Tshedeki Khama}

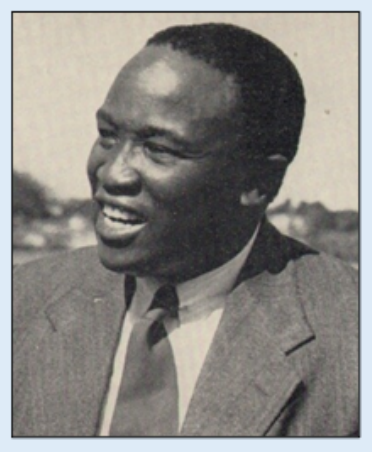

$1905-1959$

- 1925-1946: Tshekedi Khama regent of the Bamangwato Tribe

- 1950: Was forced into exile over the crisis relating to the marriage of his nephew Seretse to an English woman

- 1956: Fully reconciled with Seretse to return to Bechuanaland; also started negotiating with Rhodesian Selection Trust (RST) for a concession

- 1959: After long resisting mining companies into Bamangwato signed an mining agreement with RST for Cu mining in Phikwe

- 1959 to 1960: Consolidated African Selection Trust (CAST), part of the RST, sampled the east of Bamangwato and found 3 diamonds in the Motloutse River

Fig. 7 Summary profile of Tshekedi Khama, second son of Khama III, and regent of Bamangwato from 1926 to 1946 
Du Toit (1933) referred to a report by BSAC's mining engineer Mr WE Bennet that in 1884 diamonds had been found in the Motloutse (historic spelling Maklautsi) area whilst digging a water well. Bennet located the 70-feet deep Phiri's well in 1911, cleaned it out, but found no diamonds or associated minerals (Bennet 1911).

Work started in the Bamangwato reserve (Fig. 2) in 1932 and some 2,114 square miles was covered by 5,307 miles of traversing, walking lines $600 \mathrm{~m}$ apart while mapping and sampling. Du Toit visited the field on several occasions and also camped on the Motloutse River (du Toit, 1933).

Following disappointing results for all minerals, Victoria (AAC) withdrew its field teams in 1934. However, du Toit (1934) argued that some of the gravels discovered during this program needed to be sampled for diamonds and convinced De Beers to do so. A prospecting team from Kimberley, headed by Mr FA Wolfe and Mr Hay, was sent with a rotary pan and prospected among others a site 12 miles west of Foley Siding along the Motloutse River where they washed 200 loads ( 1 load is equal to 16 cubic feet of broken rock weighing approximately 1,600 lbs (de Villiers 1959)), as well as at Phiri's well. However, no diamonds were found at any of these locations (du Toit 1934).

In 1938, some 1163 loads were washed at Pitsane in southeast Bechuanaland from a 'pebble bed' that yielded four small diamonds (du Toit 1938). These were the first authenticated diamond finds in Bechuanaland, believed to be linked to the diamond fields near Mafikeng. Nevertheless, De Beers abandoned the Bechuanaland prospecting program in 1938.

The Bechuanaland Geological Survey was established in 1948 with EJ Wayland as the first Director. The primary function of this Department during the first 5 years was mineral 
exploration (Boocock 1965). Wayland suggested that there was no geological reason why diamonds would not be present beneath the Kalahari. He suggested that pans form over diamond pipes and suggested a systematic exploration of specific types of pans (Wayland 1949).

In his 1965 report, Boocock mentions that pyrope garnet had been reported by a mining company carrying out diamond prospecting northeast of Ghanzi, and in the Ngwezumba valley to the south of Kasane, but the property yielded no diamonds.

\section{Modern mining}

The modern exploration and mining phase started with the signing of an exploration agreement in 1959 between the Rhodesian Selection Trust Group (RSTG) and the Bamangwato Tribal Authority, leading up to the formation of the Bamangwato Concessions Ltd (BCL) Company. Tshekedi Khama had long prevented mining companies entering the Bamangwato Reserve, mainly because he did not want to create another Johannesburg or Kimberley which would destroy his tribal traditions (Crowder 1985). But only days before his death he realised that development was in fact necessary, and he signed the agreement across 42,000 square miles (Peter 1995), but preferred a company from Northern Rhodesia rather than South Africa (Murray and Parsons 1990). The agreement with RSTG was mainly focused on the extraction of copper at Phikwe, but it also provided access for Consolidated African Selection Trust (CAST), a subsidiary diamond company from West Africa, to the exposed eastern Bamangwato (Fig. 2). 
CAST took 530 stream samples (60 litres each) at roughly 5-mile intervals, and 14 bulk alluvial samples (varying from 4 to $15 \mathrm{~m}^{3}$ ) screened to a size range of +1.5 to $-4 \mathrm{~mm}$. In 1959 they found three small diamonds $(0.27,0.14$ and $0.02 \mathrm{ct})$ in the Foley area (Willis 1960). Two of the diamonds ( 0.27 and $0.14 \mathrm{ct})$ where found in the Upper Motloutse River, one $(0.14 \mathrm{ct})$ from a bulk sample, and the other $(0.27 \mathrm{ct})$ from a stream sample taken close together. The third diamond $(0.02 \mathrm{ct})$ came from another bulk sample also in a Motloutse River deposit some 17 miles downstream from the first two. According to Willis (1960) the largest stone showed some wear at its edges. No other kimberlitic minerals were found, but because of the coarse lower cutoff $(1.5 \mathrm{~mm})$ of their screens and the abundance of metamorphic minerals, including garnets, in the concentrate, the generally smaller kimberlitic minerals would be scarce and difficult to identify.

Willis (1960) concluded that the diamonds were probably derived from 'Karoo conglomerates' (Dwyka Group), and that kimberlites were therefore 'pre-Cambrian' in age. However, Willis did raise the possibility that kimberlites might occur west of the watershed in the Kalahari, but that this area had Kalahari cover and was devoid of any drainage so 'that normal prospecting methods [stream sampling] as practiced by the company [in West Africa] would not detect them' (Willis 1960).

\section{G T Lamont}

Gavin Lamont (Fig. 8) was the second and probably the most influential of the three people who charted the course of diamond exploration success in Bechuanaland. Alex du Toit was external 


\section{Gavin Thomas Lamont}

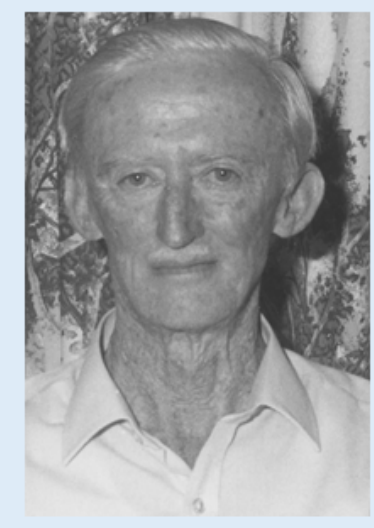

$1920-2008$

- 1947: Completed his PhD at UCT. External examiner Dr AL Du Toit.

- 1948: Joined the Geological Survey of Southern Rhodesia

- 1949 - 1955: Geological Survey of Bechuanaland Protectorate

- 1964: Suggested that the source of the diamonds of the Motloutse River was to the west of its headwaters, transported by a palaeo-Motloutse, now decapitated by Du Toit's crustal upwarp

- 1955 - 1982: Exploration Manager for De Beers/AAC (Kimberlitic Searches Ltd) in Bechuanaland/Botswana, and instrumental for the discovery of the Orapa, Letlhakane and Jwaneng mines

Fig. 8 Summary profile of Dr Gavin Lamont, who was well known for his military style sampling programs that systematically covered large tracks across Botswana 
examiner of Gavin's PhD and he talked to Alex about the prospects of working in Africa ( $G$ Lamont pers. comm. 2003). He first joined the Geological Survey of Southern Rhodesia in 1948, then the Geological Survey of Bechuanaland in 1949, and subsequently from 1955 worked for Kimberlitic Searches Ltd, a De Beers subsidiary company, in Bechuanaland, until his retirement.

Lamont adjusted the sampling technique that had been used by J Bancroft in Northern Rhodesia (Zambia) in the 1920s (de Wit et al. 2011) to better suit the environment in Bechuanaland where he firmly believed that termites were bringing minerals from the underlying geology to surface. Consequently, he introduced the continuous scoop sample method (Gibson et al. 1964), which was designed around north-south orientated baselines that were cut some 10 minutes longitude apart (approximately 10 miles). Sample teams walked 5 miles from this baseline, eastwards or westwards, one mile north or south and 5 miles back each day. A sampling team comprised between 11 and 13 men (Fig. 9). The team leader would be in front with a compass, followed by a wheel pusher with a cyclometer attached to a 28 " bicycle wheel to measure the distances (Fig. 10). Two samplers, each carrying a soil-splitter with a suspended sample bag in the one hand and a sampling shovel in the other (Fig. 10), would walk parallel to the leader about 150 yards north and south of him, respectively. Samples would therefore be collected along lines 300 yards apart centred from the baseline. Every 12 to 15 paces the samplers would take a scoop of the loose Kalahari sand (not deeper than 1 inch), which would be poured into the soil-splitter, rejecting half and passing the other half into the sample bag. At 0.2 mile, the wheel-pusher would blow his 'police-type' whistle once, to advise that the bags should be half full; and then at 0.4 mile he would blow his whistle twice to indicate that the bags should be full and be replaced by empty ones (Gibson et al. 1964). This would be equivalent to two bags 


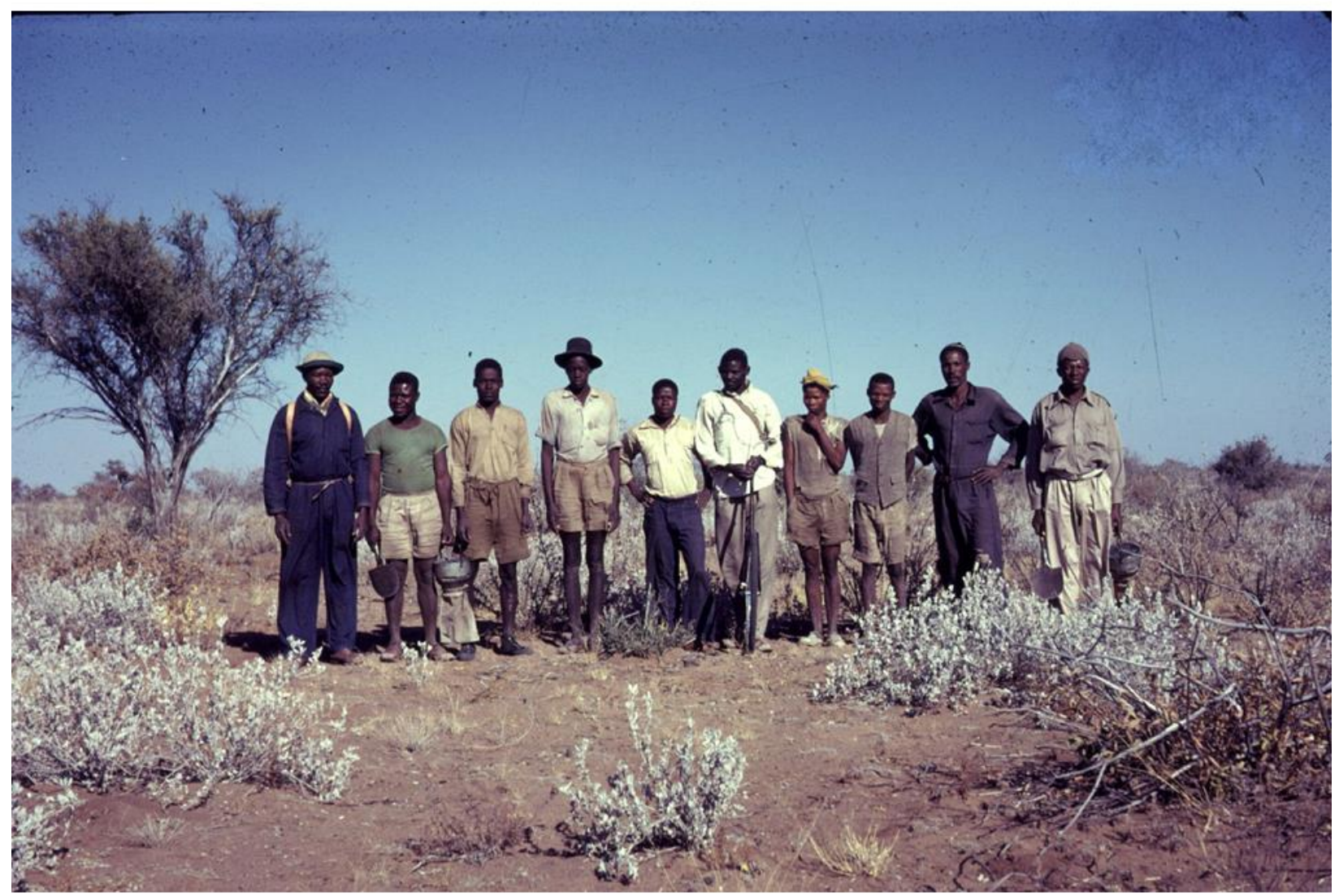

Fig. 9 De Beers sampling team, typically comprises two scoop samplers, a team leader with compass and a wheel pusher to record distances. Several porters would carry the samples back to the baseline (photo A Cessford 1962) 


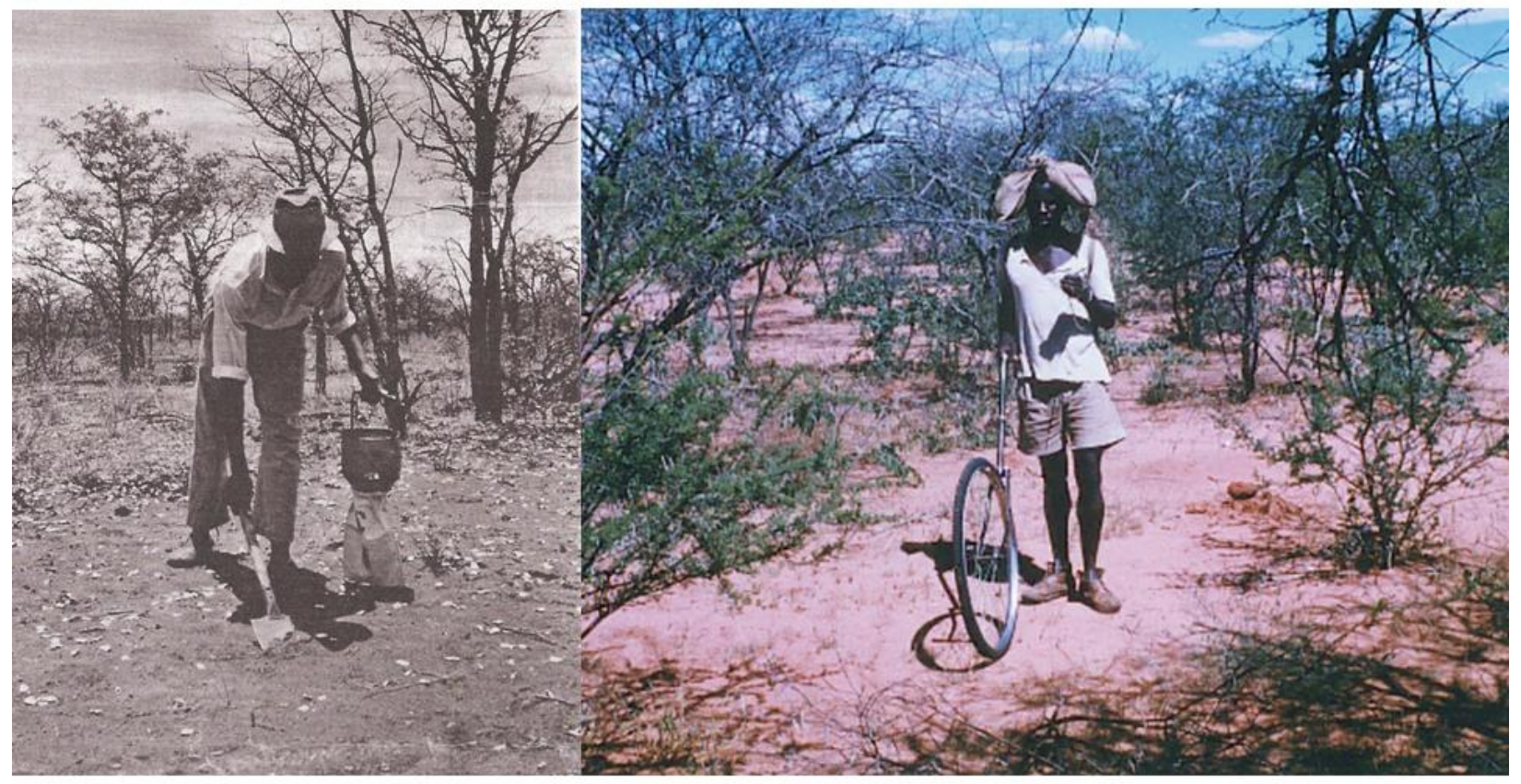

Fig. 10 Scoop sampler with sample splitter on the left (photo G Lamont 1964) and wheel pusher on the right (photo M Marx 1966) both were critical for the systematic sampling programs 
for every 0.4 mile. Each sample weighed between 8 and $9 \mathrm{lbs}$. Hence during a daily traverse of 11 miles, 54 bags would be collected weighing in total roughly $450 \mathrm{lbs}$. Porters would ferry the samples back to the baseline at regular intervals and they would 'home in' on the 'referee-type' whistles blown at regular intervals by the samplers (Gibson et al. 1964). In this manner more than $200,000 \mathrm{~km}^{2}$ of Bechuanaland was covered.

The other important change that Gavin Lamont and Jim Gibson incorporated was the introduction of screening and hand gravitation of samples in half 44-gallon drums instead of using the gold pan (de Wit et al. 2011). This proved to be a much more effective way of concentrating slightly denser material like ilmenite and garnet. The kimberlitic minerals were then hand-picked from the gravitated concentrate in the $2 \mathrm{~mm}$ (+8 mesh), $1 \mathrm{~mm}(+16 \mathrm{mesh})$, and $0.5 \mathrm{~mm}$ (+32 mesh) fractions with the aid of a wide-field hand-lens (Gibson et al. 1964).

In 1960, the Geological Survey carried out a sampling program in the upper Motloutse River area where CAST had found the 3 small diamonds. They took 4 samples of 10 (2x), 2.5 and 1 cubic yards in size, and the minus $4 \mathrm{~mm}$ fraction was retained for panning. The objective was to recover kimberlitic minerals particularly in the minus 60 mesh fraction $(0.25 \mathrm{~mm})$ (Gerrard 1963). No pyrope garnets were found, and they also concluded that the diamonds had likely weathered out of Karoo sediments and that kimberlites were probably Pre-Cambrian in age (Gerrard 1960).

In 1961 the Geological Survey conducted a systematic stream sampling campaign for heavy mineral concentrates in conjunction with regional mapping in the Bangwaketse Tribal Territory, but there are no reports of diamonds having been found (Boocock 1961). 


\section{Christopher Mark Hubert Jennings}

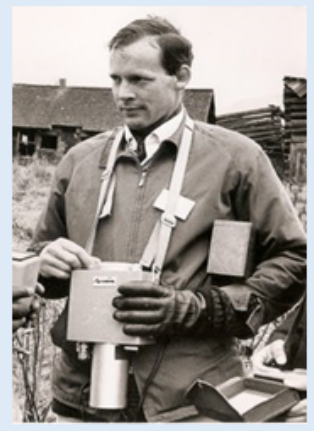

Born 1934

- 1957: Joined the Geological Survey of Bechuanaland Protectorate/ Botswana and left as Deputy Director: Gained extensive experience in geophysics

- 1966: Conducted geophysical surveys with different instruments over the newly discovered Mochudi para-kimberlites for Lamont

- 1971: Joined Falconbridge Ltd

- 1974: Completed his PhD 'The Hydrogeology of Botswana'

- 1975: Proposed to Falconbridge to explore for diamonds

- 1978-1982: Discovered some 62 kimberlites in Botswana by fast tracking exploration through extensive use of airborne geophysics and helicopter sampling

Fig. 11 Summary profile of Dr Chris Jennings. Jennings was experienced with geophysics as a hydrologist at the Geological Survey of Bechuanaland. He also surveyed the newly discovered para-kimberlites near Mochudi for G Lamont, using different geophysical techniques, and later completed some ground magnetic lines over the AK01 kimberlite 


\section{Chris MH Jennings}

Chris Jennings (Fig. 11) was the third person who had a major influence on the success of diamond exploration in Botswana. Chris joined the Geological Survey of Bechuanaland in 1957, two years after Lamont had left, but both being in Bechuanaland, they knew each other well. Chris was mainly involved in groundwater exploration, making extensive use of geophysics, and had access at the time to the most advanced instruments. He joined Falconbridge in 1971 and subsequently went on to complete his PhD in 1974 in hydrogeology of Botswana.

In 1962, Kimberlitic Searches Ltd. (De Beers), repeated the results of CAST in the Motloutse drainage (Fig. 12) and found two diamonds as well as kimberlitic indicator minerals in the samples (Lamont 1967). In March 1966 De Beers discovered two kimberlite-like intrusions near Mochudi (Jennings 1970), but these were later dismissed as lamprophyres by EMW Skinner (Lamont 1994). Lamont had asked Jennings, who was still with the Geological Survey, to carry out some geophysical surveys over these bodies using different techniques to test which would work best. Jennings concluded that the magnetic method (using an Askania Torsion magnetometer) was the most useful, while results from seismics (using a Hunting FS 2 Seismograph), electrical resistivity and self-potential (locally designed apparatus) proved to be too difficult to interpret (Jennings 1966).

After the disappointment of these bodies being para-kimberlites and at a time when De Beers was considering pulling out of Botswana (Heminway 1983), Lamont managed to convince Louis Murray from the AAC Head Office, who had taken over from Arnold Waters jnr., for a 


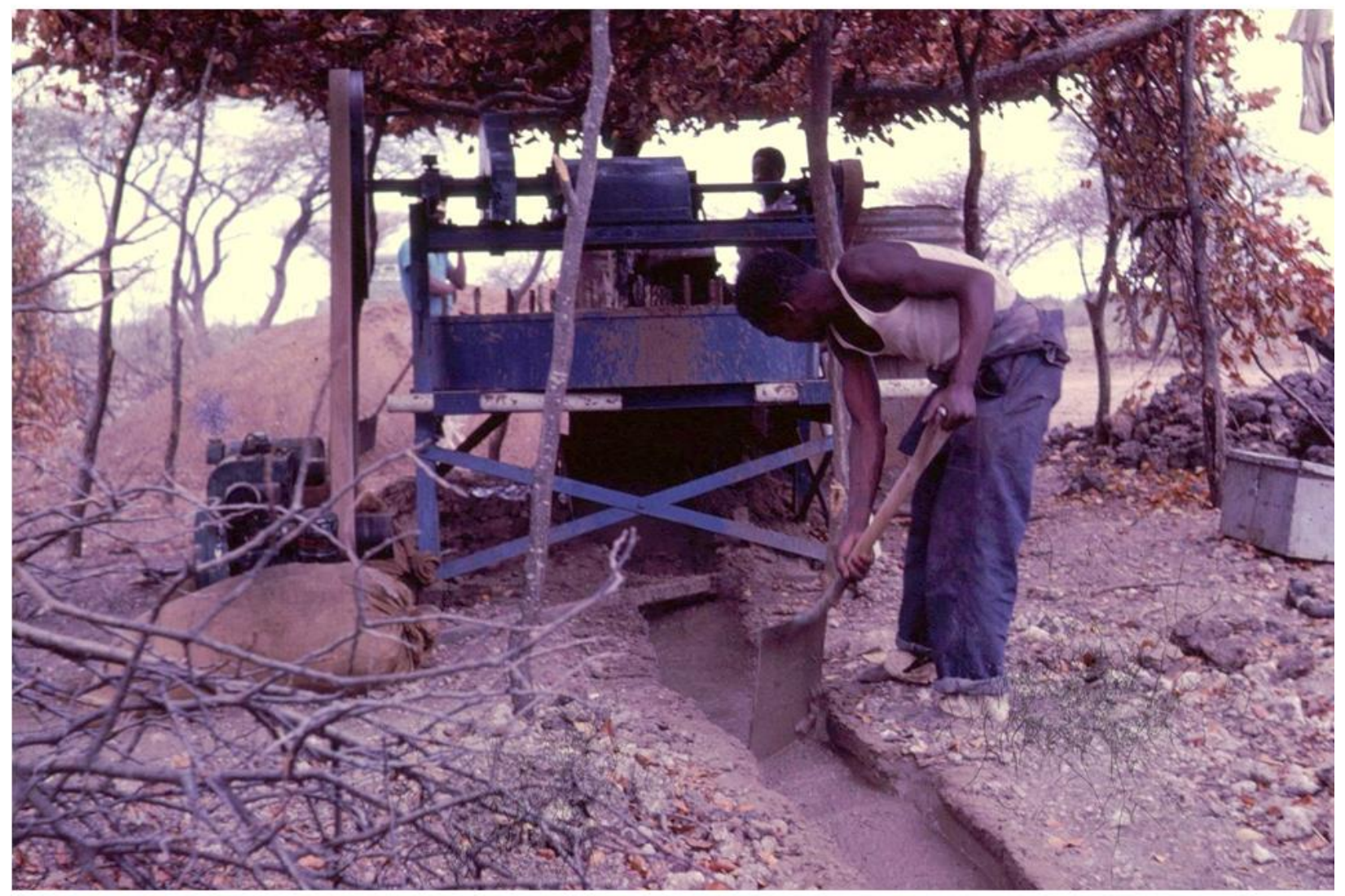

Fig. 12 Bulk sampling of the drainages in east Bamangwato using a Rotary pan recovery unit (photo A Cessford 1962) 
three-month extension, arguing that Du Toit's warping theory (du Toit 1933) might be correct (Lamont 1964). This was granted, and in July 1966 G Lamont and J Gibson collected 17 bulk scoop samples, west and beyond the headwaters of the Motloutse River but south of the Makgadikgadi pans, within an area covered by quarter degree map sheets $2125 \mathrm{~A}$ (that ultimately included Orapa mine) and 2125B (that ultimately included Damtshaa Mine). With time being of the essence they did not have the luxury of the traditional 11-mile sampling procedure, so it was a 'quick and dirty' exploration effort. Within five days, they covered some $6,000 \mathrm{~km}^{2}$ taking scoop samples for a 0.5 mile, every 2.5 miles, driving along existing tracks and roads. When camped at a small pan with little water to hand-gravitate the samples, they found garnets and ilmenites in 12 of these samples (Lamont 1994). This was two months before Botswana gained its independence.

De Beers re-applied for a Prospecting Grant covering map sheet 2125D (ultimately hosting Letlhakane Mine), which had previously been relinquished from the Crown Grant. Lamont sent young Manfred Marx to start sampling map sheets 2125A and 2125B, and six north-south baselines were cut covering those sheets. In January 1967, Marx was finding large ilmenite anomalies; and on the $1^{\text {st }}$ March 1967, he pitted into the first kimberlite found in Botswana - 2125B/K01. This was followed by 2125B/K02 on St. Patrick's Day (Lamont 1994) and on Friday the $21^{\text {st }}$ of April a highly positive sample, containing over 3,000 ilmenites, 1,000 garnets and 50 chrome-diopsides, was taken from a large feature that was marked by a small calcrete ridge. On Tuesday the $25^{\text {th }}$, Marx announced the discovery of $2125 \mathrm{~A} / \mathrm{K} 01$, now the Orapa mine. An aerial photograph taken in 1957 (Fig. 13) clearly shows the location of some of these new discoveries. The evaluation program of these early discoveries started in May 1967 using a six-foot rotary pan that was brought from Kimberley by Eben Venter and Spud Murphy 


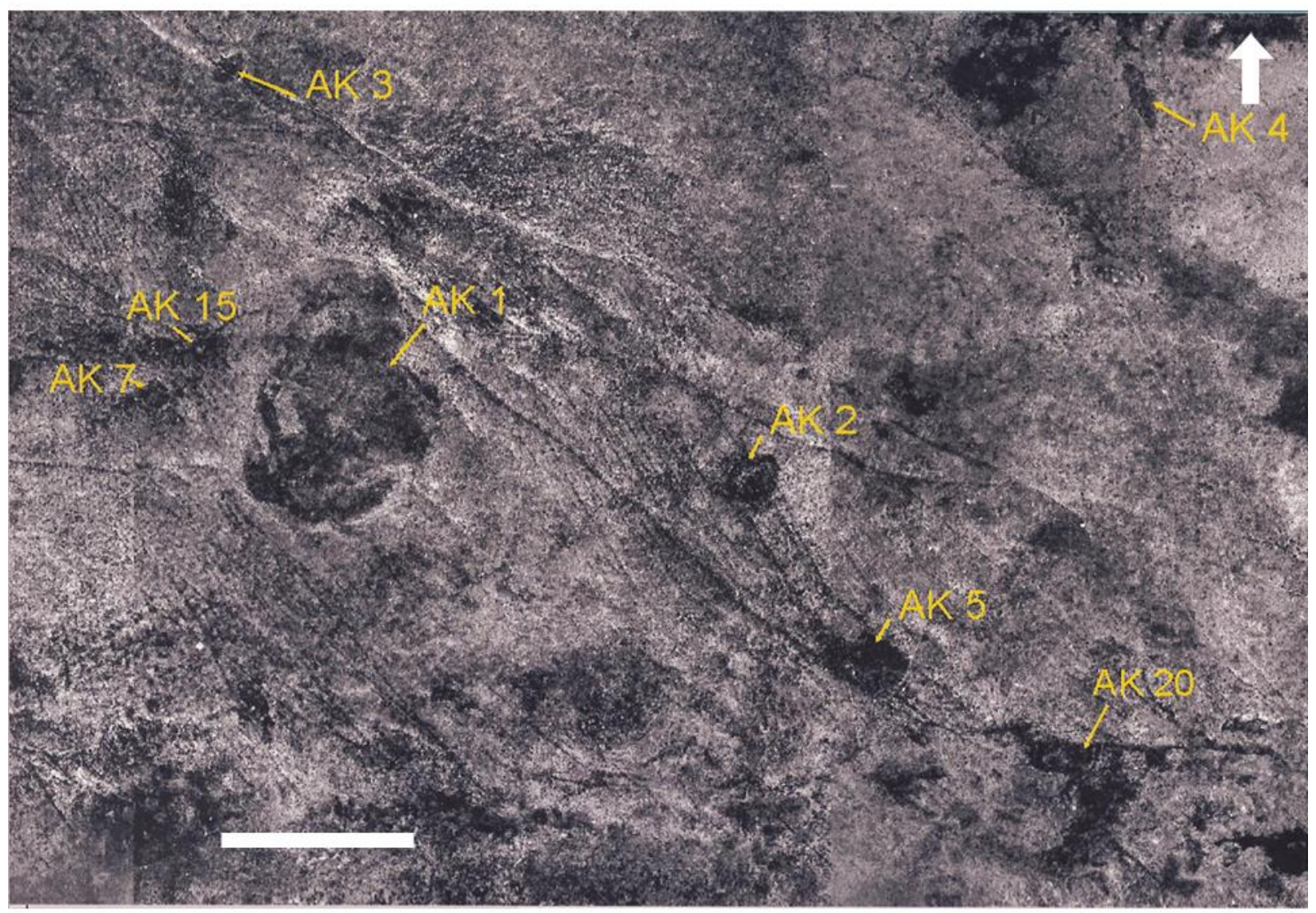

Fig. 13 Aerial photograph taken in of the Orapa cluster prior to discovery (photo no 074, line 296, 1957). White bar is $1 \mathrm{~km}$; coordinates of arrow tip of AK1 are $330946 \mathrm{~m} \mathrm{E}$ and 7642913 m S (UTM) 


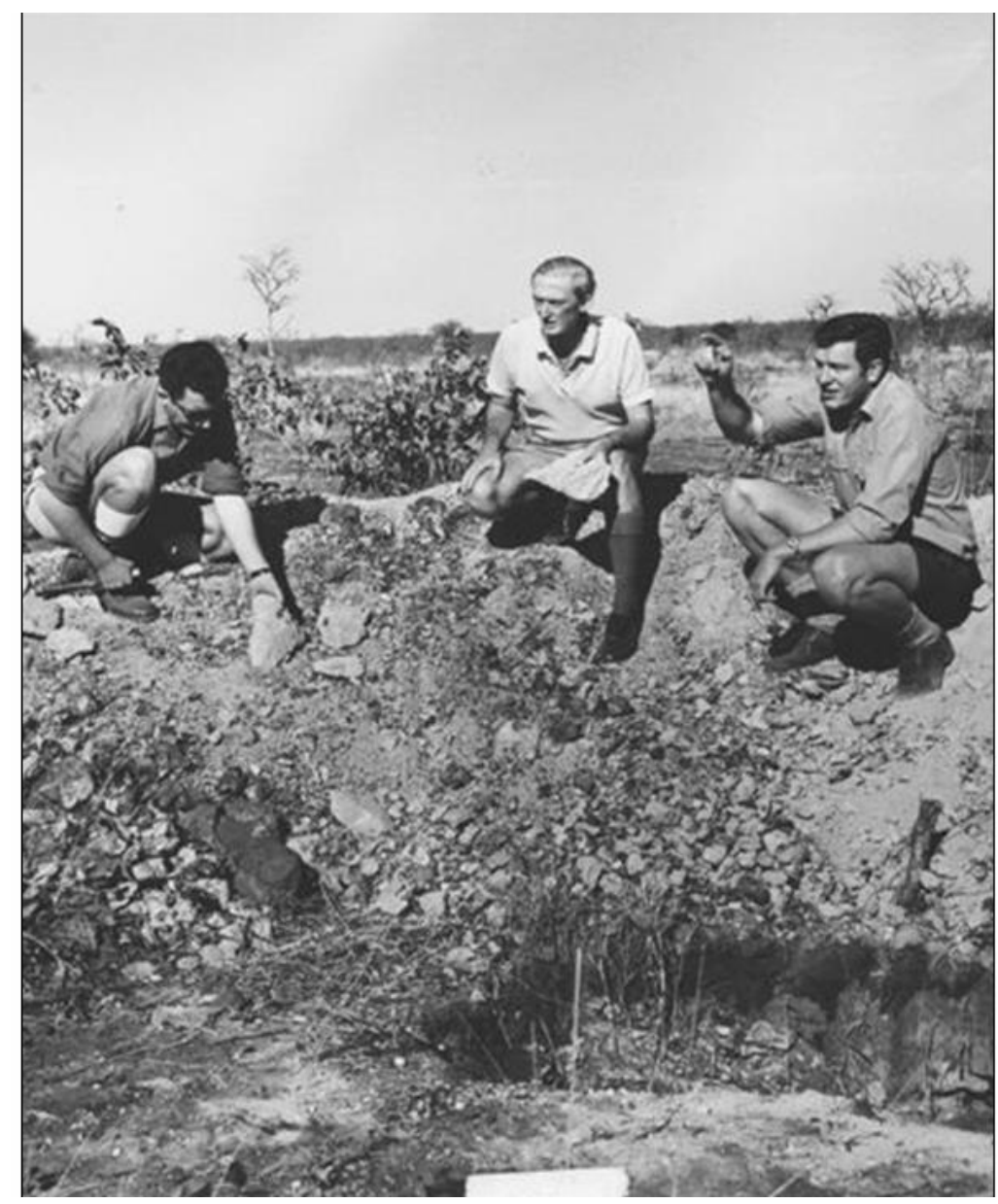

Fig. 14 Jim Gibson, Gavin Lamont and Manfred Marx next to an early evaluation pit on 2125A/K01 (photo Lamont 1967) 
(de Wit et al. 2011). It was set up at 2125B/K01, and on the $1^{\text {st }}$ June 1967 this pipe produced Botswana's first diamonds from a kimberlite. The first diamonds from 2125A/K01 were recovered on the $23^{\text {rd }}$ of June. The initial evaluation program comprised pits measuring $9 \times 9-$ feet and 20-feet deep (Fig. 14), which was followed in 1968 by 120-feet deep pits, and treatment with the use of a DMS recovery plant. In 1971 the Orapa mine was commissioned.

In 1968 G Lamont asked C Jennings to conduct some ground magnetic lines over AK01 using a Hilger and Watts magnetometer (C Jennings pers. comm. 2017). In the meantime, the AAC Geophysical Survey Department (GSD) had done some extensive tests to evaluate the merits of geophysics in Kimberley and later, in 1968, carried out experimental surveys in the Orapa area. This was highly successful and in 1969, GSD contracted Geoterrex to fly a combined magnetic and electro-magnetic airborne survey, using the Barringer Mark V INPUT (INduced PUlse Transient) system installed on a Catalina aircraft. The survey area measured 700 square miles and led to the discovery of the AK9, AK10, BK8, BK9, BK10 and BK11 kimberlite pipes (Köstlin 2001).

Meanwhile De Beers continued sampling across different parts of Botswana. Jim Gibson and Jim Platt had completed some sampling in 1962 in western Bangwaketse and close to Jwaneng, still using gold pans at the time, but found nothing. Lamont decided to return to the area using his now well-established sampling and concentrating methods in 1969 , and by the $3^{\text {rd }}$ quarter the Anglo American Research Laboratories reported the first definite ilmenites from the reconnaissance samples across the area (Lamont 1998). This was followed by detailed soil sampling (1970) and then closer detailed grid-loaming (1971), which led to four mineral anomalies: Malan 1 (2424D/K1), Malan 2 (2424D/K3), Lynn's Luck (2424D/K4) and Whateley's Wish (2424D/K2) named after some of the field geologists. With the thick Kalahari 


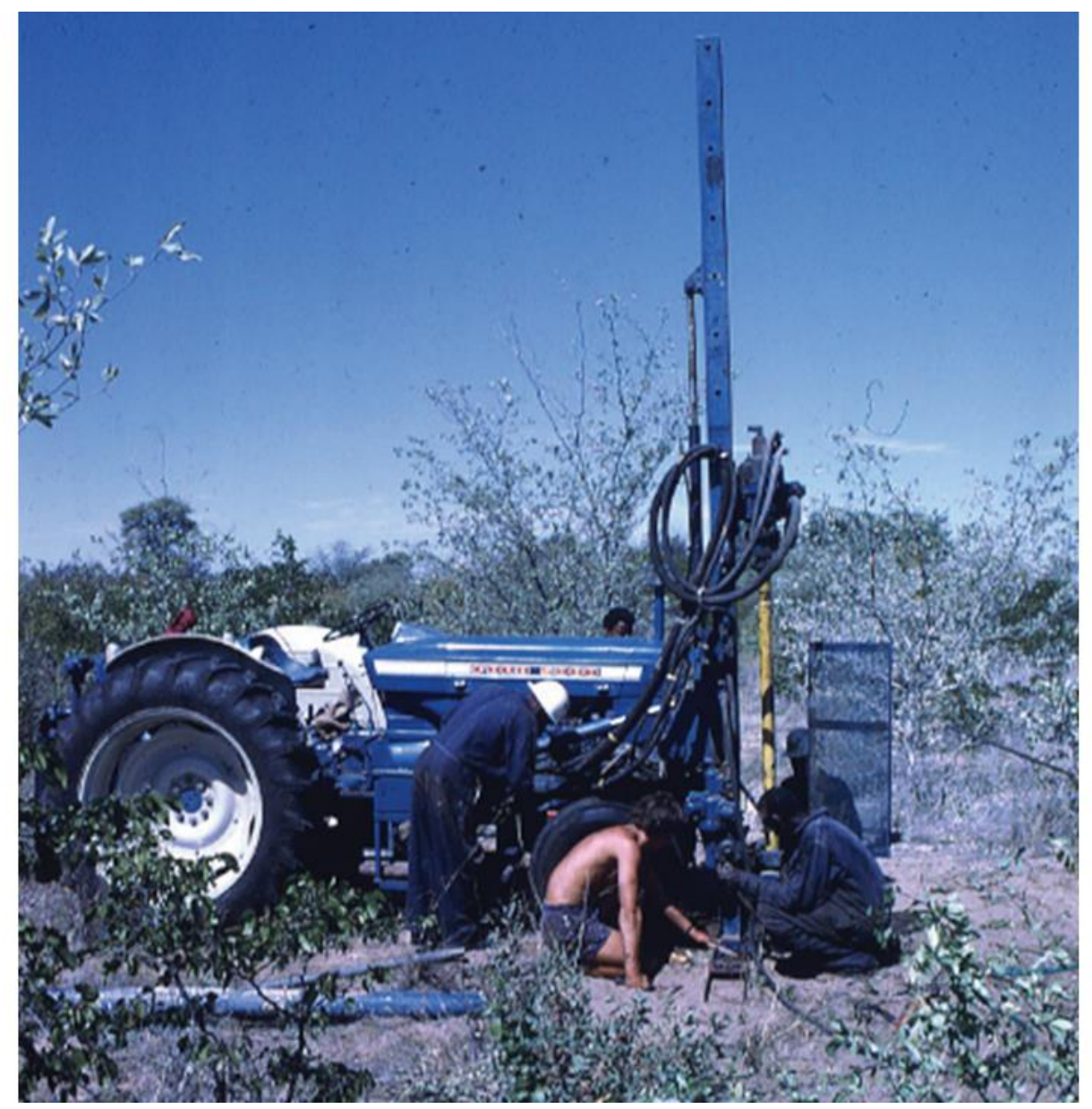

Fig. 15 The tractor mounted Vole drill used on the Jwaneng prospect (photo S Vercoe 1971) 
overburden these mineral anomalies were still diffuse, and ground magnetics also proved to be ineffective to define drill targets (Lamont 1998). Norman Lock (1985), who with Mike Whateley, Peter Bickerstaff, Simon Price amongst others was part of Stuart Vercoe's team, was able to define some drill targets using a statistical study of the sampling information. In March 1971, Malan 1 and Whateley's Wish were drilled using the tractor mounted Vole drill (Fig. 15) but it failed to intersect kimberlite. However, re-drilling of Malan 1 intersected kimberlite 2424D/K1 in March 1972. And in February 1973 two holes (46 m and $56 \mathrm{~m}$ deep), re-drilled into Whateley's Wish, intersected kimberlite (N Lock pers. comm. 2018) and confirmed the discovery of 2424D/K2. The Vole drill, which had a capacity to drill down to some $50 \mathrm{~m}$, had been used effectively at Orapa where there was no overburden. At Jwaneng the overburden was $50 \mathrm{~m}$, so it struggled to reach its targets. By mid-1979, 10 years after the first positive soil samples, eleven kimberlites, among them D/K4 (1973), D/K6 (1975), D/K7 (1976) and D/K9 (1978), had been discovered at Jwaneng.

Resource evaluation started early in 1974. But unlike Orapa, Jwaneng with its thick overburden was not conducive to pitting and it was therefore evaluated with a Large Diameter Drill (LDD), a first in any kimberlite evaluation program, using an 18-inch bit. This cable tool drill (Jumper drill) consisted of a large chisel hammering the kimberlite and a bailer to extract the sludge. It was destructive, with $26 \%$ reported diamond breakage; and drilling was slow, with drilling rates of 4 to $5 \mathrm{~m}$ per shift in the weathered kimberlite and just over $1 \mathrm{~m}$ per shift in the hard kimberlite (AA van Zyl pers. comm. 1997). This was therefore supplemented by several shafts and was later replaced by large diameter rotary percussion drilling (Lamont 1998). The mine went into production in 1982. 
In 1976 a paper entitled Gold, Base Metals and Diamonds in Botswana was published in which the Orapa kimberlite field and other groups of concealed kimberlites were highlighted (Baldock et al. 1976). It also contained a map showing all the areas that had been covered by sampling by De Beers, and also those areas with anomalous concentration of kimberlitic indicator minerals, as it is a statutory requirement to provide the Geological Survey with all raw data and results once prospecting licences are relinquished.

Jennings proposed to Falconbridge Ltd to explore for diamonds in 1975, and the joint venture between Falconbridge and Superior Oil (with Hugo Dummett) adopted a more aggressive exploration philosophy with emphasis on the early use of aeromagnetic surveys, with a broad $(500 \mathrm{~m})$ line-spacing to define ground follow-up targets. The highly committed exploration team included John Gurney as consultant on mineral chemistry, whose input was primarily responsible for a major refinement in the interpretation thereof. This was applied to rank targets for subsequent follow-up. Extensive areas were taken up by Falconbridge covering the ground that De Beers had painstakingly sampled and proven positive, such as around Tsabong and Kokong. Large airborne magnetic surveys were flown over both these areas in 1977. Targets were identified and kimberlites in the Kokong and the Tsabong areas were drilled in 1978.

With this exploration mode Falconbridge in 1980 also embarked on a helicoptersupported soil sampling program across the Central Kalahari Game Reserve (CKGR) (Fig. 16). This was revolutionary at the time, and distinctly different from the De Beers sampling approach that covered ground on foot. Consequently, Falconbridge covered an area of $78,500 \mathrm{~km}^{2}$ on a $13 \times 13 \mathrm{~km}$ grid with 470 samples within six months. The samples, unscreened, each weighed 20 $\mathrm{kg}$. Based on just four picro-ilmenites (1 coarse and 3 fine) and one peridotitic garnet $(>425 \mu \mathrm{m})$, 


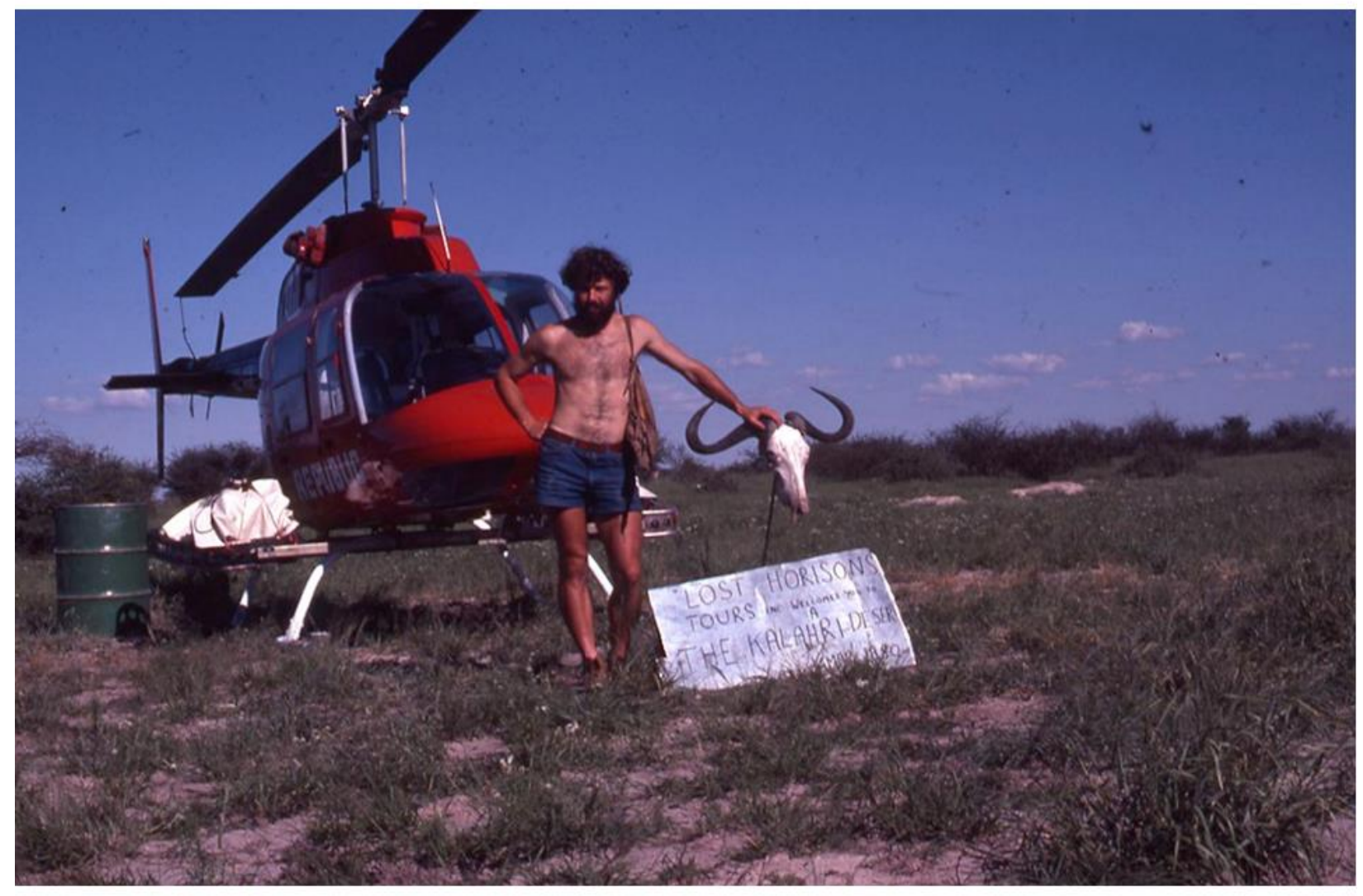

Fig. 16 Helicopter soil sampling by Falconbridge in 1980 in the CKGR that led to the discovery of the Gope kimberlite (photo A Moore 1980) 
an area was earmarked for aeromagnetic follow-up on a 500-m line-spacing. This produced a prominent bulls-eye, designated Go-25, and the Gope (Go-25) kimberlite was discovered in 1981 under Kalahari cover of some $80 \mathrm{~m}$ (Lee et al. 2009) using a jumper (cable tool) drill.

Subsequently drilling was changed to a rotary reverse circulation drill, imported and operated by SDS Drilling from Canada, rather than the traditional and much slower cable tool method. So, in the relatively short period of between 1978 and 1982 Falconbridge managed to find 62 kimberlites.

In 1982 Falconbridge and its JV partner Superior Oil concluded an agreement with De Beers to earn a 50\% interest in the Gope project. By 1998 De Beers had earned its 50\%, and in 2007 Gem Diamonds Ltd acquired 100\% of the 10.3 ha Go-25 kimberlite, which was renamed Ghaghoo.

In 1991 De Beers discovered eight more kimberlites in two groups near Martins Drift: a barren cluster (K1, 7 and 8) of 499 Ma age, and an older (1333 Ma) diamondiferous older cluster (K2-6), that later comprised the Lerala or Tswapong Mine (McGeorge et al. 2007). This was the result of reconnaissance point sampling on a $1 \times 1 \mathrm{~km}$ grid, a technique preferred on the exposed parts covered with thin residual soils. Only a few samples proximal to the kimberlites contained small numbers (between 1 and 3 grains) of kimberlitic indicator minerals (mainly garnet and spinel). Except for K8, none of the kimberlites revealed any diagnostic geophysical signature, mainly due to the complex mafic and metamorphic host rocks (Bayly 1998). De Beers Prospecting Botswana trial-mined some of the Lerala kimberlites from 1997 to 2000 and concluded they were not economic. Diamondex re-investigated these between 2008 and 2009, Mantle Diamonds in 2012 and Kimberley Diamonds between 2016 and 2017. Sadly, each time trial mining ended up in care and maintenance. 
In 2007, Petra Diamonds, while following up a subtle grain anomaly in the south-eastern part of the CKGR, that had been sampled before, discovered what appeared to be an ilmenitedeficient Group 2 kimberlite with an age of between 140 and 160 Ma (Vinès et al. 2017). This 5-ha pipe is overlain by some $78 \mathrm{~m}$ of Kalahari sediment; it is reported to have a grade between 30 and $40 \mathrm{cpht}$ (Rogers et al 2013). Evaluation of this pipe is continuing.

By 2015, De Beers returned to the Tsabong area in the southwest of Botswana and have subsequently discovered more than 20 new kimberlites in this field (MJ Roberts pers. comm. 2017).

\section{Brown Fields Exploration}

With improved metallurgical technology many known kimberlites in the Orapa field have been revisited over the last 15 years or so. A prime example is the development of AK06, which was found by De Beers early in 1970, then reported as a 3.3-ha kimberlite with a grade of 3.5 cpht. When De Beers revisited the kimberlite in 2003 it turned out to be 9.5 ha in size with a grade closer to 25 cpht. The mine was eventually taken over by Lucara in 2009 and went in to production in 2012. It has since produced some of the most magnificent diamonds including the Lesedi La Rona (1,109 ct), the second largest diamond ever found, which was sold in September 2017 for US $\$ 53 \mathrm{~m}$. Since production started the mine has produced nearly 2 mcts, which includes 145 stones each sold for more than US\$1m. The main plant upgrades include the introduction of autogenous milling and X-ray Transmission (XRT) technology to improve diamond recovery before they enter the crushing circuit to minimise diamond breakage. Other kimberlites that are 
being or have been revisited include BK1, BK9 \& 12 (Damtshaa Mine), BK15, BK17, BK11

(Firestone), AK 8, AK9 and BK16 (Tsodilo).

The Ghaghoo mine (Gope or Go25 kimberlite), was the first underground diamond mine to be developed in Botswana. It opened in 2014. Gem Diamonds constructed a decline into the kimberlite through 80 meters of Kalahari overburden. It was mined for 3 years before the low diamond prices made it necessary to put the project into care and maintenance in 2017.

\section{Summary}

Since 1967 some 397 kimberlites have been discovered in Botswana (data courtesy of De Beers Holdings Botswana Ltd. 2017), but all operating mines were found during the first wave of exploration between 1966 and 1978, all by De Beers. Falconbridge dominated the following decade during which Gope 25 was found that was later mined for 3 years. The Orapa area has been explored in three main phases: 1960s; early 1990s; and between 2003 to 2007, each time adding more but generally smaller and fewer kimberlites to the tally. All kimberlite occurrences found by sampling used mainly ilmenite as an indicator up to the 1990s. The ilmenite-poor bodies (Martins Drift, Sikwane, Thankane and more recently KX36) were found based on very diffuse anomalies all with low counts of garnet and spinel. Geophysics proved to be a 'game changer' after reconnaissance sampling had identified a kimberlite field (Orapa, Jwaneng, Kokong, Tsabong) with BK9, BK11 and AK6 among those geophysical successes (Köstlin 2001). 
Table 1 Benchmark dates relating to diamond exploration in Botswana focussed principally on economic kimberlites

\begin{tabular}{|c|c|c|c|}
\hline Date & Event & Company & Person \\
\hline $1887-1888$ & First recorded licences for precious stones - Bangwaketsi Reserve & Balkis Ltd & J Burmester \\
\hline 1896-1899 & First exploration program for diamonds - Batawana Reserve and N Ghanzi & British West Charterland Ltd & S. Passarge \\
\hline 1932-1938 & Victoria Prospecting (AAC and De Beers) prospected eastern Botswana & Anglo American/De Beers & J Bancroft/ AL Du Toit \\
\hline 1938 & First diamonds found in Botswana near Pitsane - SE Botswana & De Beers Cons. Mines & AL Du Toit \\
\hline 1959 & Three diamonds found in Motloutse River & Consolidated African Selection Trust & J Willis \\
\hline 1966 & First para-kimberlites found at Mochudi & De Beers Botswana Prospecting & J Gibson/G Lamont \\
\hline 1966 & \multicolumn{3}{|l|}{ Botswana gains independence } \\
\hline 1967 & First kimberlite found - 2125B/K01 & De Beers Botswana Prospecting & M Marx/G Lamont \\
\hline 1967 & First economic kimberlite pipe found - 2125A/K01 & De Beers Botswana Prospecting & M Marx/G Lamont \\
\hline 1968 & First airborne geophysical survey flown & De Beers Botswana Prospecting & K Biesheuvel \\
\hline 1969 & \multicolumn{3}{|c|}{ Debswana Diamond Company Ltd formed as a JV between the government of Botswana and De Beers } \\
\hline 1969 & Letlhakane $2125 \mathrm{D} / \mathrm{K} 01$ found & De Beers Botswana Prospecting & J Gibson/G Lamont \\
\hline 1970 & Discovery of $2125 \mathrm{~A} / \mathrm{K} 06, \mathrm{~B} / \mathrm{K} 09, \mathrm{~B} / \mathrm{K} 11, \mathrm{~B} / \mathrm{K} 12, \mathrm{~B} / \mathrm{K} 15$ & De Beers Botswana Prospecting & J Gibson/G Lamont \\
\hline 1971 & Orapa 2125A/K01 mine commissioned & Debswana & \\
\hline 1971 & Letlhakane $2125 \mathrm{D} / \mathrm{K} 02$ found & De Beers Botswana Prospecting & J Gibson/G Lamont \\
\hline 1973 & Jwaneng 2424D/K02 discovered & De Beers Botswana Prospecting & S Vercoe/N Lock \\
\hline 1977 & Letlhakane mine (2125D/K01 \& 02) opened & Debswana & \\
\hline 1978 & Tsabong M1 kimberlite found & Falconbridge Ltd & C Jennings \\
\hline 1981 & Gope Go25 found & Falconbridge Ltd & C Jennings \\
\hline 1982 & Jwaneng mine (2424D/K2) opened & Debswana & \\
\hline 1991 & $\begin{array}{l}\text { Martins Drift (Lerala) kimberlites found; Trail mining 1997-2000 (DB), 2008-2009 (Diamondex), } \\
2012 \text { (Mantle Diamonds), 2016-2017 (Kimberley Diamonds). }\end{array}$ & De Beers Botswana Prospecting & P Loney \\
\hline 2004 & Damtshaa mine (2125B/K01, K09, K12 \& K15) opened; (2015 - Care \& Maint.) & Debswana & \\
\hline 2007 & KX36 discovered & Petra Diamonds Ltd & J Davidson/A Rogers \\
\hline 2011 & BK11 trial mining (2012 Care \& Maint.) & Firestone Diamonds plc & \\
\hline 2012 & Karowe mine $(2125 \mathrm{~A} / \mathrm{KO6})$ opened & Lucara & W Lamb \\
\hline 2014 & Ghaghoo mine (Go25) opened (2017 - Care \& Maint.) & GEM Diamonds Ltd & \\
\hline 2015 & 1,109 ct Lesedi La Rona diamond recovered at Karowe mine & Lucara & W Lamb \\
\hline
\end{tabular}


The key points of the history of diamond exploration in Bechuanaland/Botswana are highlighted in Table 1. Although Tshekedi Khama's leadership role in the development of the mining industry has to be recognised, the success in the search for diamonds can be attributed mainly to three personalities: Alex du Toit who, with his insight on the geomorphology of Botswana and his strong belief that diamonds were to be found there and did indeed find the first diamonds; Gavin Lamont who, with his innovative sampling and sample treatment approach managed to cover large tracts and following up on Du Toit's concepts found the "jewels" of Botswana; and Chris Jennings who with his innovative usage of airborne geophysical surveys, efficient helicopter sampling and introduction of vastly improved drilling methods, discovered a large numbers of kimberlites within much reduced time frames.

As a final comment it is important to reiterate that Alex du Toit was Gavin Lamont's external PhD examiner and they knew each other well. Chris Jennings joined the Geological Survey of Bechuanaland after Gavin left but they kept in regular contact, particularly about the use of geophysics when Chris was still with the Survey. These three geologists, all innovative and all with different but complementary visions, built on each other's knowledge and experience, that turned out to be the recipe for success, from which Botswana hugely benefitted.

Acknowledgements The author is indebted to Gavin Lamont and Chris Jennings for having shared their exploration experiences. Catrien van Waarden, Manfred Marx, Jim Gibson, Andy Moore, Leon Daniels, Maarten de Wit, Eddie Köstlin, Barry Bayly, Mike Roberts and Marty McFarlane are thanked for input and discussions of various aspects of this historical summary. A review by Andrew Macdonald greatly improved this manuscript. 


\section{References}

Bayly BA (1998) Final report on Prospecting Licences 30 to 35/88 (Central District). De Beers Prospecting Botswana(Pty) Ltd, vol 1 and 2: 1-112

Bennett WE (1911) The prospecting of Khama's country. A report to the Resident Mining Engineer of the BSAC, $7 \mathrm{p}$

Bonneau A, Pearce D, Mitchell P, Staff R, Arthur C, Mallen L, Brock F, Higham T (2017). The earliest directly dated rock paintings from southern Africa: New AMS radiocarbon dates. Antiquity, 91 (356): 322-333

Boocock C (1961) Annual Report of the Geological Survey Department for Bechuanaland Protectorate, 3: $35 \mathrm{p}$

Boocock C (1965) Mineral Resources of the Bechuanaland Protectorate. In: Overseas Geology and mineral resources 9(4): 369-417

Campbell A, Main M (2003) Guide to Greater Gaborone. Campbell, Main and Botswana Society Gaborone, 292 p

Campbell A, Robbins L, Taylor M (2010) Tsodilo Hills - Copper bracelet of the Kalahari. Michigan State University Press, 180 p

Cooke CK (1979) The Stone Age in Botswana: a preliminary survey. Arnoldia 8(27): 1-32 
Crowder M (1985) Tshekedi Khama and Mining in Botswana 1929- 1959. African Studies Institute, University of the Witwatersrand, African Studies Seminar Paper 172: 1-17

Davenport J (2015) Tati - the site of southern Africa’s first gold rush. Mining weekly June 1925, p 21 and p 53

De Villiers J (Vermeulen, ed) (1959). The mineral resources of the Union of South Africa. Geological Survey of the Union of South Africa, Government Printer, Pretoria, p 50

De Wit MCJ, EO Köstlin, RS Liddle (eds) (2011) Prospecting in Africa; narratives by early De Beers explorers in the search for diamonds. Creda Communications, Johannesburg, $245 \mathrm{p}$

Du Toit AL (1927) The Kalahari and some of its problems. S Afr J Sci 24: 88-101

Du Toit AL (1931) Memorandum on the Geological investigation of the Bechuanaland Protectorate. Internal Memo to the Assistant General Manager DBCM Ltd., 8 p

Du Toit AL (1932) Remarks upon the minutes of the Victoria Prospecting Company Ltd. Internal note to HT Dickinson, $9 \mathrm{p}$

Du Toit AL (1933) Crustal movement as a factor in the geographical evolution of South Africa. S Afr J Sci 16: 3 - 20

Du Toit AL (1933) Victoria Prospecting Company Ltd, Bechuanaland. Note to HT Dickinson, Consulting Engineer, Johannesburg, 5 p

Du Toit AL (1934a) Mineral concession: Bangwaketsi Native Reserve, Bechuanaland. Unpubl. Note to HT Dickinson, Consulting Engineer, Johannesburg, 2 p

Du Toit AL (1934) Diamond prospecting operations in the Bechuanaland Protectorate. Unpublished Note to HT Dickinson, Consulting Engineer, Johannesburg, 4 p 
Du Toit AL (1938) Bechuanaland Prospecting. Unpublished Note to HT Dickinson, Consulting Engineer, Anmercosa House Johannesburg, 4 p

Ebert J (1979) The significance of archaeological sites located near or in association with ancient strandlines of Lake Makgadikgadi, Botswana. Nyame Akuma 15: 2-9

Gerrard I (1960) A report on the sampling of the bed of the Upper Maklautsi River and of the gravels in the vicinity. Geological Survey of Bechuanaland Protectorate, Report No $\mathrm{IG} / 8 / 60,4 \mathrm{p}$

Gerrard I (1963) The Geology of the Foley area. An explanation of Quarter-degree Sheer 2127C. Geological Survey Bechuanaland Protectorate, 1959/60, 35-48

Gibson JG, Joubert HP, Kramer W, Lamont GT (1964) Reconnaissance soil-sampling in Bechuanaland Protectorate. Internal report Kimberlitic Searches Ltd, 4 p

Heminway J (1983) No Man's Land: the last of White Africa. Dutton Adult, 298 p

Huffman TN, van der Merwe HD, Grant MR, Kruger GS (1995) Early Copper mining of Thakadu, Botswana. J S Afr I Min Metall 2: 53 -61

Jennings CNH (1966) Report on a geophysical survey carried out in the Mroba area, Kgatleng, in an attempt to delineate a kimberlite pipe. Geological Survey of Bechuanaland. Internal report, $4 \mathrm{p}$

Jennings CNH (1970) The discovery of diamonds in Botswana. S Afr J Sci 66(8): 233-234

Key R (1976) The Geology of the area around Francistown and Phikwe, Northeast and Central Districts, Botswana. Geological Survey of Botswana, District Memoir 3, $121 \mathrm{p}$ 
Kiyaga-Mulindwa D (1992) Iron working at Makodu in eastern Botswana. In: Sinclair P and Abdurahman J (eds) Urban Origins in Eastern Africa. The Swedish Central Board of National Antiquities, Stockholm paper 8:162-166

Köstlin EO (2001) Brief history of the discovery of kimberlite pipe BK9 (The Damtshaa - Mine) in Botswana. Internal note with 5 maps by the Consulting Geophysicist to AAC and De Beers, $5 \mathrm{p}$

Lamont G (1964) Upper Mantle Currents, Crustal Fracture and Warping and their possible influence on the distribution of kimberlite provinces and in diamond prospecting. Internal report Kimberlitic Searches Ltd., 5 p

Lamont G (1967) Renewal report for Bamangwato Crown Grant no.42 (1961-1966), De Beers Botswana Prospecting, $9 \mathrm{p}$

Lamont G (1994) The Discovery of Orapa. Unpublished memoires. Memoire 7: 1-4

Lamont G (1998) The Discovery of Jwaneng. Unpublished memoires. Memoire 15: 1-7

Lock N (1985) Kimberlite exploration in the Kalahari region of southern Botswana with emphasis on the Jwaneng kimberlite province. Conference paper on Prospecting in areas of desert terrain, Morocco, I Min Metall, pp 183 -190

McGeorge I, Clegg A, Hand P, Mothomogolo J (2007) The Lerala Diamond project and diamond exploration properties in Botswana. Competent Person's Report for Diamonex Ltd, MSA Geoservices Botswana, pp 1-118 
Moore AE, Cotterill FPD, Eckardt (2012) The evolution and ages of Makgadikgadi palaeo-lakes: consilient evidence from Kalahari drainage evolution, South-Central Africa. S Afr J Geol 115(3): $385-413$

Nash D, Coulson S, Staurset S, Ullyott S, Babusi M and Smith M (2016) Going the distance: mapping mobility in the Kalahari Desert during the Middle Stone Age through multi-site geochemical provenancing of silcrete artefacts. J Human Evolution 96: 113-133

Passarge S (1904) Die Kalahari: versuch einer physisch-geographischen Darstellung der Sandfelder des südafrikanischen Beckens, Dietrich Reimer (Ernst Vohsen), $822 \mathrm{p}$

Peter W (1995) Arbitration and renegotiation of international agreements, Kluwer Law International, $443 \mathrm{p}$

Rey CF (Parsons N and Crowder M, eds) (1988) Monarch of all I Survey: Bechuanaland Diaries 1929 - 1937. The Botswana Society, Gaborone, 282 p

Rogers SJ, Hough TG, Davidson JM (2013) KX36 - rediscovering the diamond exploration potential of the central Kalahari in Botswana. J S Afr I Min Metall 113: 593 - 545

Schwarz EHL (1920) The Kalahari, or Thirstland Redemption. T. Maskew Miller, 196 p

Summers RFH (1969). Ancient Mining in Rhodesia and adjacent area. Nat Mus Rhodesia, Salisbury, Memoir 3: 76 - 78

Tabler EC (1966). Pioneers of Rhodesia. C Struik Cape Town, 185 p

Tlou T, Campbell A (1997) History of Botswana. Revised $2^{\text {nd }}$ ed Macmillan Botswana, 278 p

Van Waarden C (1989) Archaeological Impact Assessment, Bobonong - Lekkerpoot road. Commissioned by ZMCK, Consulting Engineers for the Dept. of Roads, $27 \mathrm{p}$ 
Van Waarden C (2011) The origin of Zimbabwe tradition walling. Zim Prehist 29: 54 - 77

Van Waarden C (2012) Butua and the end of an Era. The effect of the collapse of the Kalanga State on Ordinary citizens. An analysis of behaviour under stress. Cambridge Monographs in African Archaeology 82: 148 - 153

Van Waarden C (2014) Prehistoric copper mining in Botswana. In: Selin H (ed) Encyclopaedia of the History of Science, Technology and Medicine in Non-Western Cultures. Springer Dordrecht, pp 1-13.

Vinès M, Tappe S, Stracke A, Wilson A, Rogers A (2017) Discovery of an orangeite magmatic event in the central Kalahari: Implications for the origin of southern African kimberlites. $11^{\text {th }}$ Int Kimb Conf, Gaborone, Botswana, Extended abstract No. 11IKC-4535, 3 p

Walker NJ, Segobye A (2001) Report on the archaeology of Damtshaa Mine. Unpublished mitigation report for the National Museum. Commissioned by Debswana Diamond Company (Pty) Ltd.

Wayland EJ (1949). Minerals in the Bechuanaland Protectorate. Geological Survey of Bechuanaland report EJW/16/49, $28 \mathrm{p}$ 